\title{
Analysis of Fish Market Chain: The Case of Gilgel Gibe Dam I Reservoir Southwest of Ethiopia
}

\author{
Meded Awel ${ }^{1, *}$, Zekarias Shumeta $^{2}$, Fikadu Mitiku $^{3}$ \\ ${ }^{1}$ Department of Agricultural Economics and Agribusiness Management, Jimma University, Jimma, Ethiopia \\ ${ }^{2}$ Holeta Research Institute, Holeta, Ethiopia \\ ${ }^{3}$ Collages of Agriculture and Veterinary Medicine, Jimma University,-Jimma, Ethiopia
}

Email address:

mededawol25@gmail.com (M. Awel),zakishumeta@gmail.com (Z. Shumeta), fikaddu@gmail.com (F. Mitiku)

${ }^{*}$ Corresponding author

\section{To cite this article:}

Meded Awel, Zekarias Shumeta, Fikadu Mitiku. Analysis of Fish Market Chain: The Case of Gilgel Gibe Dam I Reservoir Southwest of Ethiopia. International Journal of Economic Behavior and Organization. Vol. 8, No. 1, 2020, pp. 12-22. doi: 10.11648/j.ijebo.20200801.12

Received: November 27, 2019; Accepted: February 4, 2020; Published: April 1, 2020

\begin{abstract}
This study was aimed at analysis of fish market chain in Gilgel Gibe dam I reservoir Southwest of Ethiopia with specific objectives of investigating the fish market channels and performance and analyzing the determinants of fish supply to the market. A three stage sampling procedure which includes both purposive and random sampling were used to select sample respondents. Primary data were collected from 128 randomly selected individuals' interview using structured questionnaire via enumerators and secondary data were acquired from published and unpublished sources. Descriptive statistics and econometric analysis were used to analyze the data. The result of fish marketing channels and performance analysis shows $196,885 \mathrm{~kg}$ of fish were produced by the respondent which is $79 \%$ passed through twelve main alternative marketing channels and $16.4 \%$ was consumed by producer. The result of GMM shows the producer get the higher margin (at channel II and XII which is $75 \%$ and 73.7\%) when they sell to cooperatives and collectors and in general restaurants and hotels get the highest margin in this fish value chain (i.e. 142-146\%). The result of multiple linear regression model indicated that volume of fish supply in this study area is positively and significantly affected by fishing experience, price of fish in 2017 , producer membership to fishery cooperative and access to credit service. Therefore; it needs strong government intervention on supporting fishermen in providing modern input and technologies, empowering fishery cooperatives, strengthening of market extension and linking them with financial service provider and improving extension system are recommended to accelerate the fishery value chain's development thus income of individual fishermen could be enhanced.
\end{abstract}

Keywords: Fish Market Chain, Market Performance, Gilgel Gibe Dam I Reservoir, Multiple Linear Regression Model

\section{Introduction}

Fish is a highly traded commodity, with about 200 countries exporting fish and fishery products. Fish and fish products are particularly important for many developing nations, where the fish trade accounts for more than half of the total value of traded commodities. Developing economies saw their share rise to 54 percent of total fishery exports by value in 2012 [15]. In addition to trade, fishing and aquaculture are important to many rural poor. Fish provides a key protein source in diets as well as providing jobs and income in areas where other income sources are scarce [14].

Ethiopia is the most populous nation ( $>80$ million people) in the Horn of Africa with relatively faster rate $(2.6 \%$ per annum) of population growth [9]. The country often suffers risks of food insecurity largely due to recurring drought that affects crop production. The agriculture sector, per se, dominated by small scale farmers with low productivity could not lend itself to ensure food security and poverty alleviation to the fast growing population.

More than $85 \%$ of the Ethiopian population residing in the rural area is engaged in agricultural production as a major means of livelihood. Ethiopia is an agrarian country where agriculture remains the dominant sector of the economy contributing about $43 \%$ of the GDP, $85 \%$ of employment and $90 \%$ of total export earnings as well as providing about $70 \%$ of the raw materials for the industrial sector [11]. It is 
considered here in its broadest definition to include crops, livestock, fisheries, forestry and natural resource management.

Agricultural development led industrialization strategy is among the pillars of sustainable development and poverty reduction program in Ethiopia. In line with this strategy the Ministry of Agriculture thus considers the fishery s However, people living subsector as one of the potential intervention areas to achieve the objective of enhancing food security, employment and provide alternative sources of income to improve the livelihoods of rural people in a sustainable manner. It is also attempted to promote fish culture along with the water resource development programs such as water harvesting and formation of multifaceted reservoirs [19].

The country's water bodies are classified into four systems: lakes, reservoirs, rivers and small water bodies with substantial quantity of fish stocks. These are 12 river basins and 11 fresh and 9 saline lakes, 4 crater lakes and over 12 major swamps or wetlands [35]. The total area of the lakes and reservoirs stands at about 7000 to $8000 \mathrm{~km}^{2}$ and the important rivers stretch over $7,000 \mathrm{~km}$ in the country [5]. In addition, minor water bodies such as some of $857 \mathrm{~km}^{2}$ of reservoirs, $275 \mathrm{~km}^{2}$ small water bodies [34]. There are 180 different species of fish in Ethiopia and 30 of those are native to the country [32]. Most of the fishing so far takes place in the lakes $(85 \%)$ with only $15 \%$ in the rivers [24].

Most developing countries in the world have recognized reservoir fisheries as an effective way of increasing the supply of fish as food in rural areas at an affordable price and also provide additional income to rural farmers, thereby contributing to poverty alleviation. It added the advantages in that unlike the more conventional aquaculture practices they are less resource intensive, needs less technical skills at the farmer level and also an effective secondary user of water resources in rural areas.

It is becoming apparent that the demand for fish is increasing in the country and the market is not sufficiently supplied with fish [19]. It is far higher than the available fish in the market especially; during fasting season (March-April full month and Wednesday and Friday almost in year round) for Orthodox religion believers [4]. This is because of the supply of fish is constrained by different factors in the country. These constraints are mainly observed at three different supply chain levels (fishermen, fish traders and processors). Availability of fish and fish product to the consumers at the right time, right form, and right place and also at the lowest possible cost requires an effective marketing system [27]. Marketing of fish passes through various market channels and exchange points before it reach the final consumers [31]. On the other hand, improving marketing facilities for fish sector enable farmers to plan to their fish production and supply more in line with market demand, to schedule their harvests at the most profitable times to decide which markets to send their produce to and negotiate on a more even footing with traders. Moreover, a proper fish marketing system is also enables to increase fishermen production and supply as well as doing for more value addition on their fish. Therefore, market chain analysis is essential to understand relationships and linkages among buyers and suppliers and a range of market actors in between [28].

Fish production in Gilgel Gibe dam I reservoir has been started since the dam starts its operation and estimation model the production potential of Gilgel Gibe Dam I reservoir is estimated 371 tonne of fish per year [16]. However, people living around this reservoir have engaged in producing fish as income generating activity till the reservoir was constructed; most of them are harvesting the fish in individual basis with poor fish post-harvest management and sell their product to local market.

In addition; both buyers and sellers in the study areas usually do not play collective roles towards one another and the fishermen sells their product with very low prices and could not benefited. This was due to lack of formal fish market channel, informal linkage between actors in the fish market chain in the study area. Under such circumstances, a study that focused on the analysis of performance of chain actors and determinants of fish supply in the existing fish market chain can play significant role towards the improvements of the existing system. Because problems in the fish market chain hinder the potential gains that could have been attained from the existing opportunities. Therefore; this study was carried out with the objectives of analyzing the performance of the chain actors in the fish market chain and analyzing the determinants of fish supply to the market in Gilgel Gibe dam I reservoir of Southwest of Ethiopia.

\section{Materials and Methods}

\subsection{Location of the Study Area}

Gilgel gibe dam I reservoir is located in Oromia regional state, Jimma Zone about $260 \mathrm{~km}$ south west of Addis Ababa and $60 \mathrm{~km}$ north-east of Jimma town. It is enclosed with four Woredas namely Sekoru, Omo Nada, Kersa and Tiro Afeta; with the area coverage of the reservoir 62 square kilometers [16] and it has been operational since February 2004 [8]. Astronomically it is found within longitude and latitude of $7^{\circ} 3^{\prime}$ to $8^{\circ} 3^{\prime}$ and $36^{\circ} 7^{\prime}$ to $37^{\circ} 6^{\prime}$ with an average altitude of 1,650 m.a.s.1, annual rainfall is about $1,479 \mathrm{~mm} \mathrm{[6]} \mathrm{and} \mathrm{it} \mathrm{is}$ the reservoir of Gilgel Gibe Hydroelectric dam I. With-in these four woredas there are Eight beneficiary rural kebele's and about 12 small scale fish producer cooperatives were organized from these kebeles and engaged on fish production and marketing. The total beneficiaries (fishermen) are about 510 individuals. Its location is shown in Figure 1 as follows. 


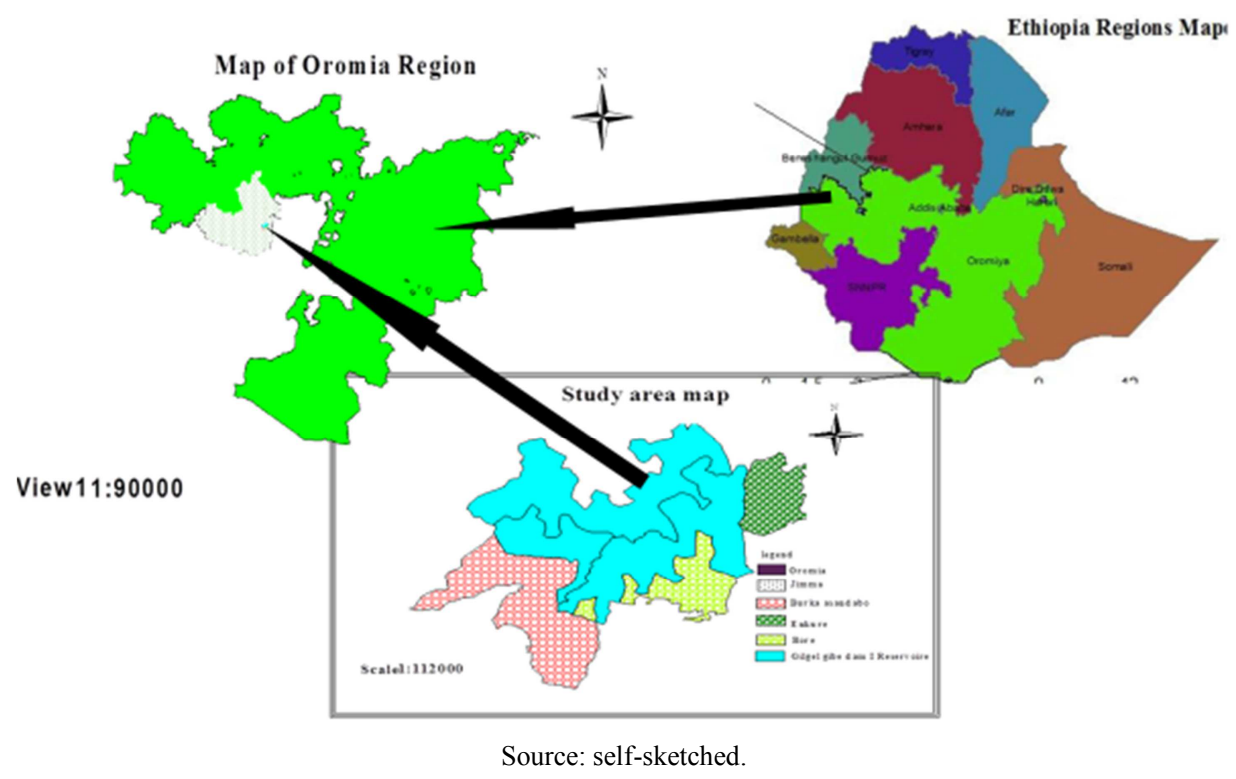

Figure 1. Map of the study area.

\subsection{Data Type, Sampling Technique and Data Collection Methods}

The primary data required for this study was collected from the key informants selected in this study area and the secondary data were collected from literature review and from related government organizations. The formal survey was done using structured questionnaire and checklist prepared for each groups. The group included all individuals participating in the market chain of fish in the study area. The informal surveys were done using Rapid Market Appraisal (RMA) technique using checklists. Accordingly; a three stage sampling procedure has been applied to select the sample respondents. In the first stage, two woredas namely Omo Nada and Sekoru were purposively selected based on their fish production potential. In the second stage, one kebele from Omo Nada (Burka Assendabo) and two kebeles from Sekoru (Hunkure and Bore) were purposively selected based on their intensity of fishing activities and in the third stage a total of 128 individuals fishermen were selected using proportionate simple random sampling methods from a total of 189 fish producer of the three selected kebeles. Finally; 4 local collectors, 4 fishery cooperatives, 3 wholesalers, 4 retailers, 4 restaurant and hotels and 10 fish consumer individual were purposively selected based on the information collected from the target respondents that for whom they sell their fish. The sample size determination was resolved by means of sampling formula with $95 \%$ confidence level [29].

$$
n=\frac{\mathrm{N}}{1+\mathrm{N}\left(e^{2}\right)}
$$

Where: - $\mathrm{n}$ is sample size,

$\mathrm{N}$ is population and $e$ is with the desired level of precision which is 0.05 .

\subsection{Methods of Data Analysis}

Two types of data analysis were applied in this study, namely descriptive statistics and econometric analysis were used. For both descriptive statistics and econometric models analysis; SPSS version 20 and STATA version 12 were employed.

\subsubsection{Descriptive Analysis}

These methods of data analysis refer to the use of percentages, mean, tabulation, frequency distribution in the process of describing the individual fish producer characteristics in the study area.

Analysis of fish market performance: Estimates of the marketing margins are the best tools to analyze performance of market. Margin analysis was used to evaluate the performance of actors in fish market chain. Marketing margin was calculated by taking the difference between producers and retail prices. The producers' share is the commonly employed ratio calculated mathematically as the ratio of producers' price to consumers' price.

Mathematically, producers' share can be expressed as:

$$
\mathrm{PS}=\frac{\mathrm{Cp}-\mathrm{Pp}}{\mathrm{Cp}} \text {. }
$$

Where; PS = producer share

$\mathrm{Cp}=$ consumer price

$\mathrm{Pp}=$ producer price (calculated as producers selling price per unit less producer's marketing cost)

Traders marketing costs: Different types of marketing costs relating to the latest transaction of fish traders and marketing costs for each actor (fishermen, local collector, fishery cooperative, wholesalers, retailers and restaurants) were recorded and calculated based on the following formula.

$$
\mathrm{AMCi}=\frac{X i Q i}{Q i}
$$

Where:-AMCi = Average marketing cost for each different kind of traders. 
i. Qi = Quantity handled during the latest transaction for each fish trader; used as a weighing coefficient.

ii. $\mathrm{Xi}=$ Different types of marketing costs of the latest transaction incurred by each fish trader.

Then, calculating the total marketing margin was done by using the following formula. Computing the Total Gross Marketing Margin (TGMM) is always related to the final price paid by the end buyer and is expressed as a percentage [23]

$$
\mathrm{TGMM}=\frac{C p-P p}{C p} X 100
$$

Where: TGMM= Total Gross Marketing Margin

From this measure, it is possible to see the allocative efficiency of markets. Higher NMM or profit of the marketing intermediaries reflects reduced downward and unfair income distribution, which depresses market participation of smallholders. An efficient marketing system is where the net margin is near to reasonable profit.

To find the benefit share of each actor the same concept was applied with some adjustments. In analyzing margins, first the Total Gross Marketing Margin (TGMM) was calculated. This is the difference between producer's (farmer's) price and consumer's price (price paid by final consumer) i.e.

$$
\text { TGMM }=\text { Consumer's price }- \text { Farmer's price }
$$

Then, marketing margin at a given stage ' $\mathrm{i}$ ' (GMMi) was computed as:

$$
\mathrm{GMMi}=\frac{S P i-P p i}{T G M M} X 100
$$

Where, SPi is selling price at $i^{\text {th }}$ link and PPi is purchase price at $\mathrm{i}^{\text {th }}$ link.

Total gross profit margin also computed as:

$$
\text { TGPM }=\text { TGMM-TOE }
$$

Where, TGPM is total gross profit margin, TGMM is total gross marketing margin and TOE is total operating expense.

Similar concept of profit margin that deducts operating expense from marketing margin was done by [10] and [21]

Then profit margin at stage " $\mathrm{i}$ " is given as:

$$
\mathrm{GPMi}=\frac{G M M i-O E i}{T G P M} X 100
$$

Where, GPMi $=$ Gross profit margin at $i^{\text {th }}$ link

GMMi $=$ Gross marketing margin at $i^{\text {th }}$ link

OE $i=$ Operating expense at $i^{\text {th }}$ link

TGPM=Total gross profit margin
The net marketing margin (NMM) is the percentage of the final price earned by the intermediaries as their net income after their marketing costs are deducted. The percentage of net income that can be classified as profit (i.e. return on capital), is depends on the extension to such factors as the intermediaries' own (working capital) costs.

$$
\mathrm{NMM}=\frac{\text { Gross marketing margin }- \text { Marketing costs }}{\text { End buyer price }} X 100
$$

Where: $-\mathrm{NMM}=$ Net marketing margin

\subsubsection{Econometric Analysis}

Several studies indicate that econometric models have the power to generate essential information on causal relationship between dependent and independent variables. An econometric model consists of a dependent and independent variables, also called explanatory variable and an error terms, or to be more precise stochastic disturbance terms, which stand for unobservable random variables not explicitly included in the model [17]. To analyze the determinants of fish supply to the market multiple linear regression models were employed.

\section{Multiple Linear Regression Models}

Multiple linear regression models are the most common form of linear regression analysis. As a predictive analysis, it is used to explain the relationship between one continuous dependent variable from two or more independent variables. It is also considered as the most commonly used statistical analysis techniques to describe the functional relationships between a dependent variable (either continuous or categorical) and a set of independent variables based on samples from a particular population [13]. In this study, multiple linear regression models were used to identify determinants of volume of fish supply to the market. The model specification of supply function in matrix notation is the following: The empirical model for this study was specified as follows: $x_{\mathrm{n}}$

$$
y=\beta_{0}+\beta_{1} x_{1}+\beta_{2} x_{2} \ldots+\beta_{i} x_{i}+\hat{\mathrm{u}}_{\mathrm{i}}
$$

for $\mathrm{i}=1 \ldots \mathrm{n}$

Where: $y=$ quantity of fish supplied to market (a continuous dependent variable)

$\beta_{0}=$ the intercept value

$\mathrm{X}=\mathrm{a}$ vector of explanatory variables $\mathrm{x}$

$\beta \mathrm{i}=\mathrm{a}$ vector of parameter to be estimated

$\hat{\mathrm{u}}_{\mathrm{i}}=$ disturbance term $\mathrm{u}$ and

$$
\begin{gathered}
Y=\beta_{0}+\beta_{1} \text { age }+\beta_{2} E d u+\beta_{3} F \exp +\beta_{4} F E q u i+\beta_{5} \text { Pday }+\beta_{6} \operatorname{Inc}+\beta_{7} A M k t A+\beta_{8} E x S e r+\beta_{9} M e C o o p+\beta_{10} \text { Pri }+ \\
\beta_{11} \text { Dismkt }+\beta_{12} \text { AcRod }+\beta_{13} \text { AcMktInf }+\beta_{14} A C+\varepsilon i
\end{gathered}
$$

\section{Results and Discussion}

\subsection{Descriptive Results}

\subsubsection{Demographic and Socio-economic Characteristics of Sample Fish Producers}

Totally all the respondents were male with an average age of
26 years which indicate that most of them are found in the young age group. The average fishing experience of targeted respondents was 4.5 years. Out of the total sample respondents $46.9 \%$ married while $53.1 \%$ are unmarried. With regarding to fishery cooperative; $41.4 \%$ of the respondent individual fish producers were members of fishery cooperatives and $58.6 \%$ of them were non- member in this study area [30]. 


\subsubsection{Fish Production Overview}

Producers used drift-nets, fishing boats, locally made boat ("Bidiru") which is made of local materials, fishing hooks, freezer and motorized boat for fish production equipment. Majority of the equipment was previously offered by World vision Ethiopia Omo Nada branch as a support to fishermen. The fish seed is applied on the reservoir by Oromia Bureau of Agriculture in collaboration with Ziway fishery research institute.

\subsubsection{Fishing Frequency}

The average fishing frequencies of individual fish producer in the study area of in the study year were 5 days with the minimum and maximum of 3 and 7 days per week respectively.

\subsubsection{Fish Production, Selling and Consumption Overview}

Fish production in Gilgel Gibe Dam I reservoir takes place all year round from the start of the dam constructed; however the peak period when the best harvesting is between February and June. Based on the survey result the average annual volume of fish production were $196,885 \mathrm{~kg} /$ year which is $33,124 \mathrm{~kg} /$ year for whole fish and $163,761 \mathrm{~kg} /$ year for semiprocessed (filleted) fish. Accordingly out of the total produced fish $16.4 \%$ were used for home consumption, $4.5 \%$ were lost in different ways and the remaining $79.13 \%$ was supplied to the market through different market channels. It is briefly indicated in table 1 as follows.

Table 1. Annual production, consumption and loss fish in the study area.

\begin{tabular}{|c|c|c|c|c|c|}
\hline Type of fish produced & Annual Production & Annual consumption & $\%$ consumed & Average Sale & \% loss \\
\hline Whole fish & 33,124 & 5,376 & & 27,748 & \\
\hline Semi-processed & 163,761 & 26,913 & 16.4 & 136848 & 4.47 \\
\hline Total & 196,885 & 32,289 & & 155,799 & \\
\hline
\end{tabular}

Source: Own computation from survey result, 2017

As indicated in the following table 2 the average selling price for whole and semi processed fish vary based on the consumption seasons. In Orthodox Christian fasting season the average price for whole fish was 9.36 and at non-fasting season was $8.78 \mathrm{ETB}$ per $\mathrm{Kg}$ respectively. The average semi processed fish price at Orthodox Christian fasting season were very higher than in non-fasting season; which were 26.31 and 15.89 $\mathrm{ETB}$ per $\mathrm{Kg}$ of fish respectively.

Table 2. Annual sale volume and selling price of fish per season in the study area.

\begin{tabular}{lll}
\hline $\begin{array}{l}\text { Type of fish } \\
\text { produced }\end{array}$ & \multicolumn{2}{l}{ Average Selling price per seasons (ETB/kg) } \\
\cline { 2 - 3 } & Fasting Season & Non-fasting season \\
\hline Whole fish & 9.36 & 8.78 \\
Semi-processed & 26.31 & 15.89 \\
\hline
\end{tabular}

Source: Own computation from survey result, 2017

\subsection{Marketing Channels and Performance Analysis}

A marketing channel is a business structure of interdependent organizations that reach from the point of product origin to the consumer with the purpose of moving products to their final consumption destination. The analysis of marketing channels is intended to provide a systematic knowledge of the flow of the goods and services from their origin to the final destination.

\subsubsection{Fish Marketing Channel}

Twelve main alternative fish marketing channels were identified in the study area. The survey result shows that $196,885 \mathrm{~kg}$ of fish were produced by the respondent fishermen and $79 \%$ or $155,799 \mathrm{~kg}$ of the produced fish were marketed in and around the study area in 2017. The main marketing channels identified from the point of production until the product reaches to the final consumer through different intermediaries were depicted in Figure 2 below. As can be understood from this Figure, the main receivers from the fish producers were fish whole sellers and fisher cooperatives with an estimated percentage share of $52.3 \%$, $30.5 \%$ respectively.

Channel comparison was made based on volume that fish produced was passed through each channel. Accordingly, the channel of Producer - wholesaler-Restaurant \& Hotels to Consumer carry the largest fish volume followed by Producer- Wholesaler - Retailers to Consumer that carry a volume of $18,740 \mathrm{~kg}$ and $18,334 \mathrm{~kg}$ of fish respectively. Very small volume of fish were passed through the channel of Producer- Local Collector - Wholesalers - Retailer Restaurant \& Hotels to Consumer (i.e. only $510 \mathrm{~kg}$ ). The reasons for this small volume of fish passing through this channel were local collectors buy small amount of fish from producer because of lack of accessing fish storage facility and fearing of fish deterioration. As a result; mostly restaurants and hotels consume fish from wholesaler because of wholesalers can supply fresh fish on time as much as possible and they do have access to storage but in rare case when there is shortage of fish supply restaurants and hotels buy fish from the retailers from Jimma town. These twelve main channels show the distribution of fish from this reservoir within Jimma region. In addition to these; there are channels which go through the traders from abroad i.e from Addis Ababa, Woliso and Wolkite and carry a volume of $69,050 \mathrm{~kg}$ of fish. The result of this marketing channel indicates $55.62 \%$ of the fish produced from this reservoir was consumed within Jimma zone and the remaining 44.32\% were supplied and traded towards the center of the country i.e. Addis Ababa. 


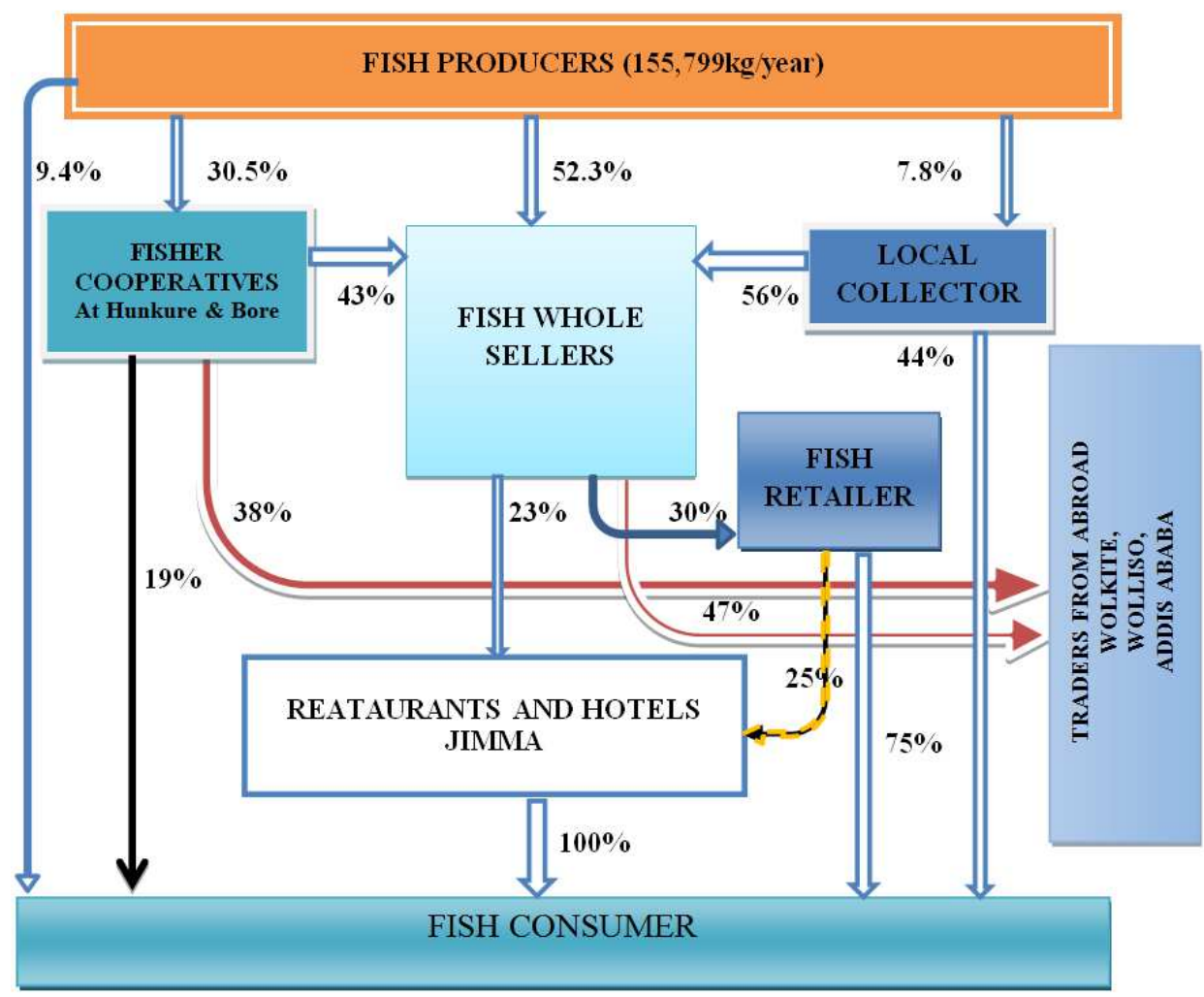

Source: Own sketch from survey result, 2017.

Figure 2. Gilgel Gibe Dam I reservoir fish market channel.

Based on figure 2 above the twelve Fish Marketing Channels were depicted as follows

I. $\quad$ Producers $\rightarrow$ Consumers $(14,645 \mathrm{Kg})$

II. Producer $\rightarrow$ Cooperatives $\rightarrow$ Consumers $(9,028 \mathrm{~kg})$

III. Producers $\rightarrow$ Cooperatives $\rightarrow$ Whole Seller $\rightarrow$ Restaurant \& Hotels $\rightarrow$ Consumers $(4,699 \mathrm{~kg})$

IV. Producers $\rightarrow$ Cooperatives $\rightarrow$ Whole Seller $\rightarrow$ Retailer $\rightarrow$ Consumers $(4,597 \mathrm{Kg})$

V. Producers $\rightarrow$ Cooperatives $\rightarrow$ Wholesaler $\rightarrow$ Retailer $\rightarrow$ Rest $/$ T\& Hotels $\rightarrow$ Consumer $(1,532 \mathrm{~kg})$

VI. Producers $\rightarrow$ Whole Seller $\rightarrow$ Restaurant \&Hotels $\rightarrow$ Consumers $(18,740 \mathrm{~kg})$

VII. Producers $\rightarrow$ Whole Seller $\rightarrow$ Retailer $\rightarrow$ Consumers $(18,334 \mathrm{~kg})$

VIII. Producers $\rightarrow$ Whole Seller $\rightarrow$ Retailers $\rightarrow$ Restaurant $\&$ Hotels $\rightarrow$ Consumers $(6,120 \mathrm{~kg})$

IX. Producers $\rightarrow$ Collectors $\rightarrow$ Wholesalers $\rightarrow$ Restaurant \&Hotels $\rightarrow$ Consumers $(1,565 \mathrm{~kg})$

$\mathrm{X}$. Producers $\rightarrow$ Collectors $\rightarrow$ Wholesalers $\rightarrow$ Retailers $\rightarrow$ Res $/ \mathrm{t} \&$ Hotels $\rightarrow$ Consumers $(510 \mathrm{~kg})$

XI. Producers $\rightarrow$ Collectors $\rightarrow$ Wholesalers $\rightarrow$ Retailers $\rightarrow$ Consumers $(1,532 \mathrm{~kg})$

XII. Producers $\rightarrow$ Collectors $\rightarrow$ Consumers $(5,347 \mathrm{~kg})$

\subsubsection{Performance of Fish Market}

The performance of fish market was evaluated by considering associated costs, returns, marketing margins and channel comparison. Analyzing the distribution of costs and gross income at different levels of marketing channels is important in the business of fishery value chain. Being highly perishable nature of the product, fresh fish require greater attention during harvesting, transporting, processing and packaging from the point of production to the final market. The marketing cost of the fish is mainly involves the cost of post-harvest activities incurred before reaching the consumer. This includes cost of harvesting and packaging (material and labor costs), handling and processing (sorting, cleaning, washing, grading, filleting, gutting, smoking, salting), transportation (loading and unloading) and tax costs. Generally, these components constitute a large share in the total margin between the final retailer price and the cost of production.

\subsubsection{Marketing Costs and Benefit Shares of Actors in Fish Market Chain}

As indicated in the following table 5; different types of marketing cost related to the transaction of fish by local collectors, fishery cooperatives, wholesalers, restaurants and hotels, retailers and the benefit share of each marketing actors; the arrangement of marketing cost revealed that perishability loss is the highest cost for fish producer and local collector. This is due to the highly perishable nature of fish and it is easily deteriorate during harvesting and carrying to market place. On the other hand packaging materials cost followed by transport and labor cost is highest for Cooperative, Wholesalers and retailers and for Restaurant and Hotels the processing cost is the highest because they apply more value addition activity to prepare fish for consumption compared to the other actors. 
Table 3. Marketing costs and benefit shares of actors per $\mathrm{kg}$ of fish.

\begin{tabular}{|c|c|c|c|c|c|c|c|}
\hline Item (Birr/kg) & Producer & Collector & Cooperatives & Whole seller & Retailer & Rest/Hotels & Horizontal sum \\
\hline Purchase Cost & - & 15.89 & 17.17 & 21.25 & 36.33 & 40 & \\
\hline Production Cost & & & & & & & \\
\hline Fishing Material and Equip & 1.73 & & & & & & \\
\hline Marketing cost & & & & & & & \\
\hline Labor and processing & 0.37 & 0.16 & 0.24 & 1.08 & 0.25 & 6.38 & \\
\hline Transport & 0.27 & 0.14 & 0.30 & 1.17 & 0.15 & - & \\
\hline Loss & 0.71 & 0.25 & 0.17 & 0.19 & 0.20 & - & \\
\hline Overhead cost & - & - & 0.25 & 0.50 & 0.25 & 10 & \\
\hline Added food material & - & - & - & - & - & 15 & \\
\hline Packing materials & 0.10 & 0.16 & 0.60 & 1.23 & 0.60 & 2 & \\
\hline Storage Cost & - & - & 0.13 & 0.25 & 0.42 & 1.88 & \\
\hline Loading Unloading & - & - & - & 0.22 & 0.12 & - & \\
\hline Tax/VAT & - & - & - & - & - & 25.58 & \\
\hline Total marketing cost & 1.45 & 0.86 & 1.69 & 4.64 & 1.97 & 60.83 & \\
\hline Total cost & 3.18 & 16.75 & 18.86 & 25.89 & 38.3 & 100.83 & \\
\hline Sale Prices & 15.89 & 17.17 & 21.25 & 36.33 & 40 & 170.5 & \\
\hline Market Margin & 14.16 & 1.28 & 4.08 & 15.08 & 3.67 & 130.5 & 168.77 \\
\hline$\%$ share of margin & 8.40 & 0.76 & 2.42 & 8.94 & 2.2 & 77.32 & 100 \\
\hline Profit margin & 12.71 & 0.42 & 2.39 & 10.44 & 1.7 & 69.67 & 97.35 \\
\hline$\%$ share of profit & 13 & 0.78 & 2.5 & 10.72 & 1.75 & 71.57 & 100 \\
\hline
\end{tabular}

Source: Own computation from survey result, 2017

Except for restaurant and hotels the profit margin of actors in the channels is lower than that of individual fishermen (i.e. relatively they do for more fish processing and value addition activity and pay more for operating expense than the other actors, and finally share more than $69.67 \%$ of the total profit margin followed by producers and wholesalers who share $12.71 \%$ and $10.44 \%$ of profit respectively. While the collector, cooperatives and retailers took only $0.42 \%, 2.39 \%$ and $1.7 \%$ of the profit margin respectively. This disproportionate share of benefits is the reflection of power relationship among actors. Fishermen shared $8.4 \%$ of the total value added while local collectors, fishery cooperatives, wholesalers, retailers, restaurants and hotels are responsible for $0.76 \%, 2.42 \% 8.94 \%$, $2.2 \%$ and $77.32 \%$ share respectively. The price change from producer's to consumer is $60.3 \%$ change on the channel finalized by retailer to Consumer and $90.7 \%$ change on the channel finalized through restaurant and hotels to consumer. This price change was due to adding more value on operating expense and adds more utility for customer satisfaction.

\subsubsection{Marketing Margins of Actors in Different Channels}

The margin calculation was done to show the distribution of share throughout the various actors as fish move from Producer and finally reach to Consumer. Marketing margin can be used to measure the share of the final selling price that is captured by a particular agent in the value chain. The relative size of various market participants' gross margins can indicate where in the marketing chain value was added and/or profits were made. In order to calculate the marketing margin of an agent the average price of fish sale for that particular agent was taken. For instance, the buying price of consumers was obtained by taking the average purchasing price of consumers. In order to measure the market share of each agent the marketing channel where all agents have participated was selected. GMMp, GMMc, GMMcoop, GMMret, GMMw and GMMres\&hot are gross marketing margins of producers, local collectors, cooperatives, retailers, wholesalers and restaurants and hotels, respectively. NMMcol, NMMcoop, NMMret, NMMw, NMMres\&hot are net marketing margins of local collectors, wholesalers', restaurants and hotels and retailers, respectively. Marketing margins, associated costs and benefit share of value chain actors and marketing margins through different main channels is presented in table 4 below.

Table 4. Marketing margins of actors in different marketing channel of fish (in\%).

\begin{tabular}{|c|c|c|c|c|c|c|c|c|c|c|c|c|}
\hline Marketing Margin & $\mathbf{I}$ & II & III & IV & $\mathbf{V}$ & VI & VII & VIII & IX & $\mathbf{X}$ & $\mathbf{X I}$ & XII \\
\hline TGMM & 0 & 25 & 90.5 & 58.8 & 90.3 & 91.2 & 62.5 & 91.2 & 91.8 & 91.8 & 65 & 26.3 \\
\hline GMM p & 100 & 75 & 9.5 & 41.2 & 9.7 & 8.8 & 37.5 & 8.8 & 8.2 & 8.2 & 35 & 73.7 \\
\hline GMM col & - & - & - & - & - & - & - & - & 2.2 & 2.2 & 3 & 19 \\
\hline GMM coop & - & 22 & 2.2 & 3.4 & 2.2 & - & - & - & - & - & - & - \\
\hline GMM ret & - & - & - & 8.5 & 5.5 & - & 8 & 5.5 & - & 5.5 & 7.7 & - \\
\hline GMM w & - & - & 21.6 & 28 & 18 & 25 & 32 & 22 & 24 & 20.7 & 29 & - \\
\hline GMMres\&hot & - & - & 146 & - & 145 & 145 & - & 143 & 144 & 142 & - & - \\
\hline NMM coop & - & 92.3 & 0.3 & 4.3 & 0.3 & - & - & - & - & - & - & - \\
\hline NMM ret & - & - & - & 16.3 & 2.1 & - & 15 & 2.1 & - & 2.1 & 14.3 & - \\
\hline NMM w & - & - & 9.95 & 58.4 & 7.8 & 11.9 & 68.4 & 10.2 & 11.4 & 9.4 & 60.9 & - \\
\hline NMM res\&hot & - & - & 50 & - & 49.4 & 49.4 & - & 48 & 48.8 & 47.6 & - & - \\
\hline
\end{tabular}

Source: Own computation from survey result, 2017. 
The total gross marketing margin (TGMM) is the highest in channel III, V, VI, VIII, IX and X which is about greater than $90 \%$ and in these channels Restaurants and hotels have got the highest gross marketing margin (i.e. 142-146\%). In average retailers got the lowest marketing margin through overall channels (i.e. 5.5 and $8.5 \%$ in channel $\mathrm{V}$ and IV). Without considering channel I (where producers sell their fish directly to consumer) producer's share (GMMp) is highest at channels II and XII (which is 75\% and 73.7\%) at where they sell to cooperatives and collectors respectively and lowest in channel III, V, VI, VIII, IX and X at where the consumer purchase from restaurants and hotels. In these channels restaurants and hotels purchase fish relatively at a lower price from their customer and finally sell at higher price for consumer.

The NMM were highest in channel II and XII for cooperatives and local collector as they directly purchase from producer and sell it to the final consumer, average at channels IV, VII and XI for wholesalers and channels III, V, VI, VIII, IX and X for restaurant and hotels; while the lowest III, V, VIII, IX and X where Cooperative's and local collectors bought and sell their fish with very few price difference and retailers at channel V, VIII and X bought from wholesalers and sell to the customers.

\subsection{Econometric Results}

\section{Determinants of Fish Supply to the Market}

In the study area fish were produced for market and home consumption. It is the important source of income for individual producers. According to the result of this study, all sample individual fish producer are good suppliers of fish to the market. Multiple linear regression models were employed to identify the determinants that affect fish supply to the market. For the parameter estimates to be efficient, unbiased and consistent assumptions of classical linear regression (CLR) model should hold true. Hence, multicollinarity and Heteroscedasticity detection test were performed using appropriate test statistics.

Test for Multicollinarity: the variance inflation factor (VIF) was employed to test the existence of multicollinarity problem among explanatory variables. VIF shows how the variance of an estimator is inflated by the presence of multicollinarity [33]. All values are less than 10. This indicates absence of serious multicollinarity problem among independent variables. Test for Heteroscedasticity: the imtest was employed to test the existence of Heteroscedasticity problem. The result of imtest shows absence of Heteroscedasticity problem.

Fourteen explanatory variables were hypothesized to determine the individual level fish supply to the market such as: age of the individual fish producer (Age), Education level (EDLEV), fish production experience (EXPRCE), fishing equipment (FISHEQP), number of production day per week (PRODAY), additional means of income other than fishing (AmICoF), access to competitive marketing agent (ACoMktA), access to extension service (ExtServ), individual fish producer membership with any fishery cooperative (MeCoop), price of fish in 2017 (PriF2017), distance from the nearest market (DistMkt), access to all weather road (ACCROAD), access to market information (ACCMKINF) and access to credit services (AC). Table 5 shows the analysis results of those variables.

Table 5. Factors affecting fish supply to the market.

\begin{tabular}{|c|c|c|c|c|}
\hline Variables & Coefficient & St. Error & $\mathbf{t}$ & $\mathbf{P}>/ \mathbf{t} /$ \\
\hline Age & .093 & .059 & 1.56 & 0.121 \\
\hline Education Level & .364 & .260 & 1.40 & 0.164 \\
\hline Fishing Experience & .694 & .177 & 3.92 & $0.000 * * *$ \\
\hline Fishing and processing Equipment & .072 & .810 & 0.09 & 0.930 \\
\hline Production day per week & .482 & .248 & 1.94 & $0.055^{*}$ \\
\hline Means of income other than fishing & -.983 & 639 & -1.54 & 0.127 \\
\hline Access to competitive marketing agent & .164 & .811 & 0.20 & 0.840 \\
\hline Membership to fishery cooperatives & 1.093 & .580 & 1.88 & $0.062 *$ \\
\hline Price of fish in 2017 & .863 & .174 & 4.96 & $0.000 * * *$ \\
\hline Distance from the nearest market & -.242 & .301 & -0.80 & 0.424 \\
\hline Access to all weather road & .661 & .686 & 0.96 & 0.337 \\
\hline Access to market information & .067 & .591 & 0.11 & 0.911 \\
\hline Access to credit & 1.336 & .636 & 2.10 & $0.038 * *$ \\
\hline Constant & -13.421 & 3.530 & -3.80 & $0.000 * * *$ \\
\hline $\mathrm{R}^{2}$ & & 0.5600 & & \\
\hline $\mathrm{N}$ & & 128 & & \\
\hline
\end{tabular}

Note: Dependent variable is volume of fish supplied in $\mathrm{Kg} . * * *, * *$ and $*$ are statistically significant at $1 \%, 5 \%$ and $10 \%$, respectively.

Source: Own computation from survey result, 2017.

Out of fourteen explanatory variables only Five of them such as: fish production experience (EXPRCE), number of production day per week (PRODAY), price of fish in 2017 (PriF2017), individual fish producer membership to fishery cooperative (MeCoop) and access to credit services (AC) are significantly affects the volume of fish supply to the market in the study area.

Fish Production Experience (EXPRCE): It affects fish 
market supply positively and significantly at less than $1 \%$ significance level. The result suggests that as farmers get high fish production experience the amount of fish supplied to the market increased through its effect on fish production. Thus, the result implied that as fish producer individual fishing experience increases by a year; the supply of fish to the market increases by $0.694 \mathrm{~kg}$. This is in line with [1] who illustrated as farmer's experience increased the volume of tomato supplied to the market increased and [3] as farmer's experience increased by a year, potato supplied to market increased by a unit.

Number of production day per week (PRODAY): The result of multiple linear regression models for this study shows the number of fish production days per week affects fish supply to the market positively and significantly at less than $10 \%$ significance level. The result suggests that as the number of fish production day per week increases by one unit, the amount of fish supplied to the market increases by $0.482 \mathrm{~kg}$.

Individual fish producer membership to fishery cooperative (MeCoop): Membership to fishery cooperative affects fish supply to market positively and significantly at $10 \%$ significance level. The result shows that as the individual fish producer getting the opportunity to be a membership of fishery cooperative increase by one unit; the quantity of fish supplied to the market increases by $1.09 \mathrm{~kg}$; because of an individual fish producers worry to whom they sell their fish product after produced. It means, if they get the opportunity to bea member of fishery cooperative, their fish production and supply to the market through their cooperative increases. This is in-line with [26]; who found that membership of cooperatives influences the adoption of improved fisheries technologies resulting in higher productivity and supply to market.

Price of fish in 2017 (PriF 2017): It affects fish supply to market positively and significantly at less than $1 \%$ significance level. The result suggests that the unit variation of fish price affects the daily production and supply of fish to the market in the study area. Thus, the result implied that as the price of fish on the market increases by one unit, the supply of fish to the market by individual fish producer increase by $0.863 \mathrm{~kg}$. This is in line with [3]; who found that the price of fish is positively and significantly related to the probability of selling fish.

Access to credit services (AC): Credit is an important element starting from buying of fishing equipment up to the marketing of the fish product at the market place. It affects fish supply to market positively and significantly at less than $5 \%$ significance level. The result shows that a unit increase of an individual fish producers accessing to credit service; increases the fish supply to the market by $1.34 \mathrm{~kg}$. This is in line with [25] who illustrated that those farmers who have access to formal credit, are more probable to supply marketable wheat than those who have no access to formal credit.

Finally, The $\mathrm{R}^{2}$ value of the model is 0.56 and adjusted $\mathrm{R}^{2}$ value is 0.53 (Table 5). It was observed that the adjusted coefficient of determination was more than 53 percent in the marketable supply function, implying that more than 53 percent of the variations in marketable supply were explained by the explanatory variables.

\section{Summary and Conclusion}

This study was conducted with the aim to analyze fish market chain in the case of Gilgel gibe dam I reservoir southwest of Ethiopia with the specific objectives of investigating the fish market channels and performance and analyzing the determinants of fish supply to the market.

The result of descriptive analysis pointed out that, the average daily fish production per individual producer during the survey year was $5.92 \mathrm{~kg}$ /day and the average volume of fish production of the targeted respondent were $196,885 \mathrm{~kg} /$ year, $79 \%$ of the produced were supplied to the market, $16.4 \%$ was used for home consumption and $4.5 \%$ of fish was lost by deteriorating before it reaches to market. As the survey result indicated the average annual income for individual fishermen was 26,925.35 ETB/person/year in 2017 which is $103.56 \mathrm{ETB} /$ day/person.

The fish market channels and performance analysis result revealed that twelve main alternative fish marketing channels and chain actors were identified. The main fish market chain actors are fishermen, fishery cooperatives, local collectors, wholesalers, retailers and restaurants and hotels. The main marketing channels which receive fish directly from the producer are fish whole sellers and fishery cooperatives with an estimated percentage share of $52.3 \%$ and $30.5 \%$ respectively. Channel comparison was made based on volume that fish produced and passed through each channel. Accordingly, the channel of Producer - wholesalerRestaurant \& Hotels to Consumer carry on the largest fish volume followed by Producer- Wholesaler - Retailers to Consumer that carry a volume of $18,740 \mathrm{~kg}$ and $18,334 \mathrm{~kg}$ of fish respectively and the very small volume of fish were pass through the channel of Producer- Local Collector Wholesalers - Retailer - Restaurant \& Hotels to Consumer (i.e. only $510 \mathrm{~kg}$ ).

The performance of fish market was evaluated by considering associated costs, returns and marketing margins i.e. the methods employed were channel comparison and marketing margin. Compared to fish producer, except local collectors the other traders' (Cooperatives, wholesalers, retailers) marketing costs are a little higher than the producer and restaurant and hotels operating expense is much higher than that of individual fish producer. But their profit margin is lower than that of individual fish producer farmers except for restaurant and hotels (i.e. Restaurants and hotels pay more operating expense and shares more than $69.67 \%$ of the total profit margin. Without considering channel I (where producers sell their fish directly to consumer) producer's share (GMMp) was highest at channels II and XII at where they sell their fish to cooperatives and collectors respectively (which were $75 \%$ and $73.7 \%$ ) from the total consumers' price and in general restaurants and hotels have got the highest 
GMM. This disproportionate share of benefits is the reflection of power relationship among actors.

With regard to econometrics results; in identifying the determinants of fish supply to the market fourteen explanatory variables were hypothesized and only five of them such as: fish production experience (EXPRCE), number of production day per week (PRODAY), price of fish in 2017 (PriF2017), individual fish producer membership with fishery cooperative (MeCoop) and access to credit services (AC) were significantly affects the supply of fish to the market in the study area.

\section{Recommendation}

Based on the findings of this study, the following policy measures could be recommended, because there is a need for the promotion of fish production and volume of supply to the market.

To start with descriptive result, regarding to the characteristics of fish producer most of them engaged on production of fish as individual basis, only $41.4 \%$ of them were organized under small scale fishery cooperative. Because of this they have no power to access modern fishing and fish processing equipment. Therefore; effort should be made to strengthen fishermen cooperative and encourage collective action of stakeholders to make the fishermen benefited.

Secondly, the result of market channel and performance analysis the marketing costs and benefit shares of actors in fish market chain the arrangement of marketing cost revealed that perishability loss is the highest cost for fish producer. This is due to the highly perishable nature of fish and easily deteriorates during harvesting and carrying to market place and lack of modern fishing and processing equipment. Hence; fish producers are price taker and the chain is governed by fish trader. Therefore; it needs strong government intervention on the support of modern input technologies such as production and processing equipment, fish storage facility, cold transportation facilities are essential in increasing the production and productivity of fish and the produce stay long as well as increase the benefit of the fishermen.

Thirdly, the results of multiple linear regression model analysis indicated that the determinants of volume of fish supply to the market in the study area were positively and significantly affected by fish production experience, frequency of production day per week, price of fish in 2017, access to credit services and membership to fishery cooperatives. Therefore, these factors must be promoted in order to increase the volume of fish marketable supply. Supporting fishermen in upgrading their knowledge through provision of training and awareness creation on sustainable way of fish production and supply to the market. Facilitating for access of information to get the daily price change and facilitating for financial service provider to strengthen their purchasing power to buy the modern fishing equipment. Strengthening the supportive activities such as information centers and input supply systems and building the asset base of the farmers and developing the skills what farmers have through experience increases fish supply to the market. In addition to that, the government should encourage the fish producer farmers to be organized under strong fish producer cooperatives and promote different types of fishery cooperatives such as fish processors at rural area around the reservoir and fish produce receiver cooperatives at urban level to increases fish supply to the market.

\section{References}

[1] Abay A., 2007. Vegetable market chain analysis in Amhara National Regional State: the case of Fogera woreda, South Gondar zone. M.Sc thesis presented to the school of graduate studies, Haramaya University. Pp 70.

[2] Abraham T., 2013. Value Chain Analysis of Vegetables: The Case of Habro and Kombolcha Woredas in Oromia Region, Ethiopia. MSc Thesis presented to the School of Graduate Studies, Haramaya University. pp 41.

[3] Anthony O. Onoja, B. B. Usoroh, D. T. Adieme, N. J. Deedam, 2012. Determinants of Market Participation in Nigerian Small-Scale Fishery Sector: Evidence from Niger Delta Region. The Journal of Sustainable Development Vol. 9, Iss. 1 (2012): 69-84.

[4] Assefa, M. (2013). Assessment of fish products demand in some water bodies of Oromia, Ethiopia: International Journal of Agricultural Science. ISSN: 2167-0447, Vol. 3 (8): 628632 .

[5] Assefa, M. (2014). Fish Production, Consumption and Management in Ethiopia. Research Journal of Agriculture and Environmental Management. ISSN: 2315 - 8719, Vol. 3 (9): 460-466.

[6] Bahiru G., 2010. Environmental impact monitoring for gilgel gibe I dam using an integrated methods of remote sensing and geographic information system (GIS): Addis Ababa University.

[7] Béné, C., Heck, S. (2005) Fisheries and the millennium development goals: solutions for Africa. pp. 14-18. In NAGA, World Fish center quarterly Vol. 28 No. 3 \& 4. Penang, Malaysia.

[8] CEE Bank watches Network, 2008. The Gilgel Gibe Affair, An analysis of the Gilgel Gibe hydroelectric projects in Ethiopia.

[9] CSA (2008) Summary and statistical report of the 2007 population and housing census: population size by age and sex. Central Statistic Authority, Addis Ababa, Ethiopia.

[10] Dawit G., 2010 Market Chain Analysis of Poultry. The case of Alamata and Atsbi-Wemberta woredas of Tigray Region. An MSc Thesis Presented to School of Graduate Studies of Haramaya University. 50-56P.

[11] Demese C., Berhanu A., John M., 2010. Ethiopia's Agricultural Sector Policy and Investment Framework from 2010 - 2020. Ministry of Agriculture, Addis Ababa, Ethiopia.

[12] FAOUN, 2014. The State of World Fisheries and Aquaculture. Opportunities and challenges, Rome. Page 10-26. 
[13] Fatah, 2013, Multiple Linear Regression Analysis. sphweb.bumc.bu.edu/...Multivariable/BS704_Multivariable7.h tml. January 17, 2013. Boston University School of Public Health.

[14] Food and Agriculture Organization of the United Nations. Many of the world's poorest people depend on fish. June 7, 2005. http:// www.fao.org/NEWSROOM/en/news/2005/102911/index.html

[15] Food and Agriculture Organization of the United Nations. The State of World Fisheries and Aquaculture 2014: Part 1: World Review of Fisheries and Aquaculture. May 2014. http://www.fao.org/3/a-i3720e/i3720e01.pdf

[16] Gashaw T. and Matthias W., 2014. The state of inland fisheries in Ethiopia: a synopsis with updated estimates of potential yield. Eco-hydrology \& Hydrobiology 14 (2014): 200-219.

[17] Gujarati, Damodar N. 1988, Basic Econometrics. $2^{\text {nd }}$ edition. McGraw-Hill Book Company. New York.

[18] HLPE, 2014. Sustainable fisheries and aquaculture for food security and nutrition. A report by the High Level Panel of Experts on Food Security and Nutrition of the Committee on World Food Security, Rome 2014.

[19] Hussien Abegaz, Gashaw Tesfaye \& Abebe Cheffo, 2010. Fishery Development Program: Riverine Fishery Assessment in Gambella Peoples' Regional State.

[20] Manasi, S., Latha, N. and Raju, K. V. 2009. Fisheries and livelihoods in Tungabhadra Basin, India: Current status and future possibilities. Working Paper 217, the Institute for Social and Economic Change, Bangalore.

[21] Marshal N., 2011. Value chain analysis of sugarcane: The case of Kalu district, South Wollo zone of Amhara National Regional state, Ethiopia. M.Sc thesis submitted to the School of Graduate Studies, Haramaya University. 83p.

[22] McCormick, D. and Schmitz, H., 2001. Manual for Value Chain Research on Homeworkers in the Garment Industry, Nairobi, Kenya.

[23] Mendoza, G., 1995. A premier on marketing channel and margins. Lyme Rimer Publishers Inc., USA.
[24] MoARD (2009). Annual Report.

[25] Muhammed U., 2011. Market Chain Analysis of Teff and Wheat Production in Halaba Special Woreda, Southern Ethiopia, MSc thesis Reported to School of Graduate Studies Of Haramaya University, 88p.

[26] Olaoye, O. J. and Odebiyi, O. C. (2011). Economic viability for the use of microfinance bank loan on aquaculture development in Ogun State, Nigeria. International Journal of Fisheries and Aquaculture, 3 (4), 70-77.

[27] Shamsuddoha, M. (2007). Supply and value chain analysis in the marketing of marine dried fish in Bangladesh and nontariff measures (NTMs) in International trading. 1-11. http://ideas.repec.org/p/ags/eaa106/7941.html.

[28] Wenz, K. and W. Bokelmann, 2011. Incorporating value chain research and problem-based learning into horticulture and agriculture study programs in Kenya and Ethiopia. HumboldtUniversität zu Berlin, Faculty of Agriculture and Horticulture, Department of Agricultural Economics, Berlin, Germany.

[29] Yamane, Taro. 1967. Statistics: An Introductory Analysis, 2nd Ed., New York: Harper and Row.

[30] Meded A., Zekarias Sh., Fikadu M.. 2018, Analysis of Fish Value Chain: The Case of Gilgel Gibe Dam I Reservoir, Southwest of Ethiopia.

[31] Ali, E. A, H. I. M., Gaya and T. N. Jampada (2008). Economic Analysis of fresh fish marketing in Maiduguri Gamboru Market and KachallariAlau Dam landing site of Northeastern Nigeria. 4: 23-26.

[32] The Monthly Publication from the Ethiopian Embassy in London Ethiopian News, January, 2012.

[33] Gujarati, D. N., 2003. Basic Econometrics. 4th Edition. McGraw-Hill, New York. Pp. 563-636.

[34] Mesfin Assefa, 2012. The Fourth Annual Conference of the Ethiopian Fisheries and Aquatic Sciences Association (EFASA).

[35] MCE (Metaferia Consulting Engineers). 2001. Assessment of Experiences and Opportunities on Medium and Large scale Irrigation in Ethiopia, Addis Ababa: Ethiopia. 